DePARTAMENTO DE TGCNICA DE SAUDE PUBLICA

(Diretor: Prof. Dr. Geraldo H. de Paula Souza)

CADEIRA DE HIGIENE PRE-ESCOLAR E ESCOLAR

(Prof. Dr. Vicente de Sampaio Lara)

\title{
INTOXICAÇÃO PELA INGESTÃO DE "SAIA BRANCA"*
}

\author{
Drs.: LUUIZ AUGUSTO DE TOLÉDO \\ PAULO DE BARROS FRANÇA ASSISTENTES \\ CORNELIO PEDROSO ROSENBURG
}

Dentre os vários casos de intoxicação atendidos no Pavilhão Condessa Penteado, da Santa Casa de Misericórdia de São Paulo, avultam em número os causados pela ingestão do vegetal conhecido vulgarmente por "saia branca".

O quadro clínico da intoxicação pela "saia branca" é bastante característico, mas, à pesar disso, o diagnóstico deixa freqüentemente de ser feito em virtude de não pensar o médico nessa possibilidade.

O caso seguinte é bastante demonstrativo do que acabamos de afirmar.

Recentemente foi enviada ąo Serviço uma criança com o diagnóstico de meningite. Tratava-se de um menino de 2 anos que, até há 15 dias, convivera com a mãe, portadora de tuberculose aberta. A doença da criança, se iniciara sùbitamente, tendo o paciente, de um momento para outro, entrado em estado de alheiamento ao ambiente, apresentando-se, logo em seguida, agitado e delirante. Foi levado a um médico, que não estabèleceu diagnóstico e enviou o paciente a um hospital, onde se levantou a hipótese de tratar-se de meningite. Foi feita punção lombar, obtendo-se liquor claro.

Com o diagnóstico provável de meningite tuberculosa, o doentinho foi enviado à Santa Casa, onde o vimos.

Logo de início chamou-nos a-atenção o estado de agitação da criança, que se movia continuamente no leito, executando movimentos com as mãos, como se procurasse apanhar objetos no espaço.

Não havia rigidez de nuca, Kernig ou Brudzinski. As pupilas se apresentavam dilatadas e nãó reagiam à luz. O rosto estava ligeiramente corado. Pulso, 130 por minuto. Nada mais de importância ao exame físicc.

U'ma história mais detalhada revelou que a criança, 12 horas antes, depois de ter estado brincando no quintal, entrara em casa com um olhar estranho, muito corada, "vermelha da côr da chupeta", como dizia a informante.

Nem a história, nem o quadro clínico, como se vê, lembravam meningite tuberculosa.

A referência à vermelhidão súbita nos fez pensar que se tratasse de um caso de intoxicação pela "saia branca".

(*) - Consideraçōes a propósito de 18 casos observados no Pavilhão Condessa Penteado, da Santa Casa de Misericórdia de São Paulo. - Serviço do Professor Pinheiro Cintra. 
Indagamos então da informante se não hávia em cảsa êssè vegetal. A resposta foi afirmativa e foi-nos dito mais que a criança estivera brincando. sob êsse arbusto (que na ocasião estava florido) pouco antes de adoecer.

A hístória nos pareceu muito típica e os achados clínicos bastante stugestivos, de modo que estabelecemos o diagnóstico de intoxicação pela "sain branca". Recomendamos luminal sódico e líquidos em abundância. Logo em seguida à injeção de luminal a criança adormeceu e, 24 horas depois, estava completamente curada.

Como se vê, tratava-se de um caso bastante característico, cujo diagnóstico não foi estabelecido pelos colegas que nos precederam, pelo simples fato de não terem pensado na possibilidade de intoxicação por êsse vegetal.

E com o fito exclusivo de divulgação, e para chamar a atenção dos colegas para êsses casos, que fazemos a presente publicação.

\section{O QUE E A "SAIA BRANCA"}

A "saia branca" ou "trombeteira." é um arbusto que às vezes atinge a. três metros de altura. E muito encontradiça entre nós, crescendo nos terrenos baldios e sendo também cultivada em alguns jardins, como planta ornamental. Suas flores se assemelham aos modelos antigos de saias brancas, ou a trombetas, donde os nomes que o vulgo the deu.

Não dispomos de referências exatas sobre a distribuição dêsse vegetal nos demais Estados brasileiros, mas acreditamos que pode ser encontrado. em todo o País.

As fotografias 1 e 2 mostram o arbusto florido, as de número $3,4,5$ e6 mostram, respectivamente, os botões, a flor e o fruto da "saia branca".

O exame das fotografias que acompanham êste trabalho ajudará os colegas de outras cidades a fazer a identificação dêsse vegetal.

Os botões florais da saia branca têm o aspecto de "bananinhas" ou quiabos, segundo a expressão das crianças. Os frutos, çomo se vê na fotografia, apresentam no seu interior inúmeras sementes.

A "saia branca" perténce ao gênero Datura, da família das Solanaceas. As espécies dêsse gênero, mais comuns entre nós, são a D. suaveolens Humb. \& Bonpl. e uma variedade desta, cujas flores apresentam os bordos da corola côr de salnã̃o, e a D. arborea Linn. Ambas as espécies são conhecidas por "saia branca" "ou "trombeteira".

Segundo o Prof. F. C. Hoehne, (1) ilustre diretor do Instituto de Botânica do Estado de São Paulo, essas duas espécies apresentam os seguintes caracteres que permitem diferençá-las:

Datura suaveolens Humb. \& Bonpl.: anteras conglutinadas; cálice inflado, anguloso, glabro, em regra normalmente dentado, igualando dois têrços do tubo da corola.

Datura arborea Linn.: anteras livres; cálice roliço, pubescente, irregularmente aberto ou espatiforme fendido, igualando o comprimento da parte tubulosa da corola.

Nos jardins cultiva-se, também, entre nós, a $\mathbf{D}$. fastuosa Linn., de porte arbustivo e flores roxas. 
Aparecem asselvajadas, nas taperas e lugares de entulho, a D. stramonium Linn. (conhecida vulgarmente por "figueira do inferno"), a D. tatula Linn. e a D. ferox Linn., que poderão provocar intoxicação.

A "saia branca" floresce entre nós sobretudo enı outubro, novembro, dezembro, janeiro e fevereiro, meses, portanto, em que as intoxicações ocorrem com maior freqüência.

As crianças comumente se intoxicam ingerindo os botões florais, que comparam a bananinhas ou quiabos. A ingestão dos frutos, das sementes ou das fôlhas, também intoxica.

$\mathrm{Na}$ série que estudamos tivemos 17 casos de intoxicação pela ingestão de botões e 1 devido à ingestão de sementes. A maior frequência de envenenamentos pela ingestão de botôes se deve ao fato de as flores atrairem mais a atenção das crianças do que os frutos. Com efeito, o aspecto da planta, tôda florida, atrai as crianças. Além disso, os botões servem de brinquedo, pois, comprimidos ràpidamente, arrebentam, produzindo um estalo.

As plantas que vimos estudando pertencem aos vegetais chamados do grupo da Atropa belladona, e, como essa, pertencem à família das Salonaceas. Como a beladona, contêm principalmente atropina e hiosciamina. Ambas contêm também escopolamina, além de outros alcalóides.

Interessa-nos particularmente, no caso, estudar as efeitos da atropina e da escopolamina.

Esses alcalóicles exercen duas ações principais no organismo: ưma, sôbre o sistema nervoso central, cujo mecanismo é desconhecido; outra, e mais importante do que a anterior, sôbre dos músculos lisos e sôbre certas glândulas secretoras. No sistema nervosio central a atropina provoca excitação do bulbo e dos centros cerebrais elevados. Em doses terapêuticas a atropina provoca excitação moderada dos centros respiratórios; quando empregada em doses tóxicas, à excitação provocada se segue depressão, sendo que, nos casos de morte por intoxicação pela atropina, esta se deve à paralisia bulbar.

A escopolamina, outro alcalóide presente na "saia branca", apresenta um efeito sôbre o sistema nervoso central que contrasta com o da atropina. De fato, enquanto a atropina estimula e depois deprime o cérebro, a escopolamina é primàriamente depressora e, em doses terapêuticas, normalmente provoca sonolência, fadiga e sono sem sonhos. As vézes, porém, dosea terapêuticas dêsse alcalóide provocam excitaçãa inquietação, alucinação e delírio. Alguns, mas nem todos êsses efeitos paradoxais, podem ser devidos à idiosincrasia pelo alcalóide.

Efeitos periféricos - Os alcalóides do grupo da beladana impedem a resposta dos músculos lisos e células glandulares aos impratsos colinérgicos. A atropina e a escopolamina diferem quantitativamente nos seus efeitos periféricos. A escopolamina bloqueia a iris, o corpo ciliar e certas glândulas secretoras, como as salivares, brônquicas e sudoríparas. O efeito da atropina é mais pronunciado e mais prolongado do que o da escopolamina, no coração, intestinos e músculos bronquiolares. Tanto a atropina como a es. copolamina provocam midríase e paralisia da acomodação. Outros efeitos da atropina, como secura das membranas mucosas, taquicardia, vermelhi. dẩo cutânea, são por demais conhecidos para serem aqui relembrados. O aumento da temperatura corporal, frequentemente observado nos casos de intoxicação pela beladona, é devido principalmente à inibição exercida sôbre as glândulas sudoríparas. Há casos em que a temperatura sobe a 42,5 graus. 
Absorçã̀o e eliminação - Os alcalóides do grupo da beladona são absorvidos ràpidamente pelo trato gastro-intestinal. A absorção pode dar-se também quando se faz aplicação local de preparados de beladona nas mucosas, como, por exemplo, quando se faz instilação nos olhos.

Os alçalóides desaparecem ràpidamente da circulação. Nos' tecidos, especialmente no fígado, a atropina é destruía por hidrólise do éster em tropina e ácido trópico. O restante é eliminado na sua maior parte dentro de 14 horas pelos rins. No leite de nutrizes intoxicadas podem-se encontrar traços de atropina. Este alcalóide atrạvessa fàcilmente a barreira placentária e entra na circulação fetal.

Intoxicação - Do ponto de vista toxicológico, a atropina e a escopolamina são os dois alcalóides do grupo da beladona que maior interesse apresentam. No emprêgo clínico dêsses medicamentos pode ocorrer intoxicação por ingestão ou pela instilação nos olhos, quando são usadas doses elevadas. A ingestão de flores, fôlhas ou sementes de vegetais que contenham êsses alcalóides é outra fonte de intoxicação.

Sintomatologia da intoxicação $-\mathrm{O}$ envenenamento pela ingestão acidental de vegetais que contenham os alcalóides que vimos estudando, frequentemente nãa é diagnosticado. Isso é o que se observa, não só em nosso meio, mas, também, na América do Norte.

L. M. Sportman, $\left({ }^{2}\right)$ autora norte-americana, em publicação recente, estudando 2 casos de intoxicação pela ingestão de frutos da Datura stramonium, diz que êsse tipo de envenenamento frequentemente deixa de ser diagnosticado na América do Norte. Jennings ( $\left.{ }^{3}\right)$ é da mesma opinião.

Uma das descrições mais antigas dos sintomas do envenenamento pela beladona é a de Hughes e Clark, citados por Goodman e Gilman $\left(^{4}\right)$. Trata-se de uma intoxicação coletiva pela ingestão de um vegetal do grupo da beladona, a D. stramonium, ocorrida nos Estados Unidos da América do Norte em 1676. Um agrupamento de soldados, após a ingestão de uma salada dêsse vegetal, apresentou sintomas de intoxicação. Os efeitos dessa intoxicação foram "uma comédia muito engraçada, pois os soldados ficaram possuidos de verdadeira loucura". Uns sopravam penas no ar, enquanto outros as alvejavam com flechas. Um dêles sentou-se em uma elevação do terreno, completamente despido, "fazendo caretas como um macaco". O estado de excitação apresentado por êsses soldados foi tão grande que tiveram de ser confinados "para evitar que, em sua loucura, se destruissem a si mesmos.".

Os sintomas da intoxicação aparecem ràpidamente após a ing"estão da droga. A bôca se torna sêca e ardente, a deglutição e a fala se tornam difíceis ou impossiveis. A sêde é. intensa. A visão está perturbada. Fotofobia presente. A pele se apresenta sêca, quente e vermelha. Pode aparecer um "rash" no rosto, no pescoço e na parte superior do tórax. A temperatura corporal sobe, sobretudo nas crianças, podendo chegar, nos lactentes, a 41 ou 42 graus e às vezes mais. De um modo geral há taquicardia, sobretudo nas crianças maiores, pois nas pequenas ela não é tão acentuada. Pode ocorrer dificuldade na miç̧ão.

O paciente intoxicado pelos vegetais do grupo da beladona se aprèsenta inquieto, excitado, confuso, com fraqueza geral, obnubilado e com incoordenaçãa muscular. Náusea e vômitos às vêzes estão presentes. O com- 
TOEFDO, FRANÇA E ROSENBURG. - INTOX. PGLA "SAIA BRANCA" 291

portamento e os sintomas mentais apresentados pelos doentes podem faze pensar em psicose aguda. Com efeito, L. M. Sportman, já citada, psiquia tra norte-americana, refere 2 casos de intoxicação pelo estramônio, que lh foram enviados como se fossem casos psiquiátricos.

De fato, os distúrbios mentais são acentuados. A memória está pertui bada, assim como a orientação. Aiucinações, sobretudo visuais, são frequen tes. Mania e delírio não são raros.

Têm sido feitos diagnósticos de esquizofrenia aguda e delírio alcoólic em casos de intoxicação pelos alcalóides do grupo da beladona.

Os sintomas da intoxicação persistem por vạ́rias horas e, às vezes, du ram dias.

Depressão e colapso circulatório ocorrem sòmente em casos de intoxi cação grave. A morte pode dar-se por paralisia respirátória.

\section{DIAGNÓSTICO}

$\mathrm{O}$ aparecimento súbito de perturbações visuais, dilatação e rigidez pr pilares, eritema, mucosas sêcas, taquicardia, devem fazer pensar nesse tip de intoxicação. A história bem apurada frequentemente irá mostrar que criança adoeceu sủbitamente, quando brincava fora de casa, no quintal o num terreno baldio. Muitas vezes um companheiro do doente informa qu estiveram brincando junto de um pé de "saia branca" ou conta, mesmo, qu o paciente ingeriu flores ou frutos deesse vegetal. Outras vezes os casos d envenenamento são múltiplos.

Quando houver suspeita de envenenamento pela "saia branca" deve-s verificar se êsse vegetal não está florido no momento. Já vimos que a "sai branca" floresce sobretudo nos meses de outubro, novembro, dezembro, ja neiro e fevereiro.

Os sintomas mentais podem desviar a atenção do médico dos sintoma cutâneos, mucosos, oculares etc., leviando-o a um diagnóstico errôneo de ps copatia aguda.

Qualquer indivíduo que adoeça sùbitamente, diz L. S. Sportman, e qu apresente sintomas mentais e neurológicos bizarros, deve ser suspeitado $d$ estar envenenado por droga, sobretudo por beladona.

\section{EVOLUÇÃO}

Faz-se geralmente para a cura. Os casos fatais de intoxicação pe! atropina e escopolamina são raros, apesar da grande atividade farmocoli gica dessas drogas.

A dose fatal de atropina para adultos é, provàvelmente, de 100 miligr: mas. e, para crianças, de 10 miligramas. Todavia; há casos de cura após ingestão de doses maiores.

\section{TRATAMENTO}

Lavagem gástrica, nos casos de intoxicação recente, usando-se soluçâ de ácido tânico a $4 \%$. Administrar purgativos salinos, para facilitar a el minação de folhas, flores ou sementes que ainda se encontrem no trato $d$ 
estivo. Não há vantagem na administração da pilocarpina, que é antagoista da atropina, pois ela apenas combateria alguns sintomas da intoxicazo, como secura das mucosas; mas não teria efeito sôbre as manifestações ervosas.

Quando a excitação é grande, os sedativos, como os barbitúricos, estão idicados.

Se houver depressão respiratória acentuada, deverá ser feita. respiração rtificial, administrando-se ao mesmo tempo mistura de $\mathrm{CO} 2$ e $\mathrm{O} 2$. Os anaípticos estão também indicados nesta última eventualidade. $O$ paciente everá ser mantido adequadamente hidratado.

\section{RESUMO DOS CASOS POR NÓS OBSERVADOS}

otal de casos

lade - variável de 2 a 9 anos.

Distribuição por idade:

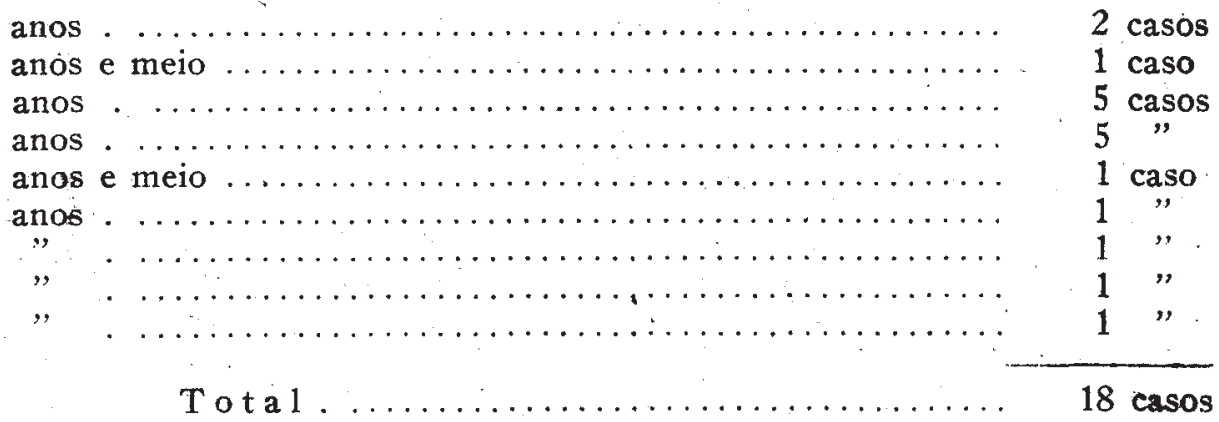

Distribuição de acôrdo com os meses do anọ:

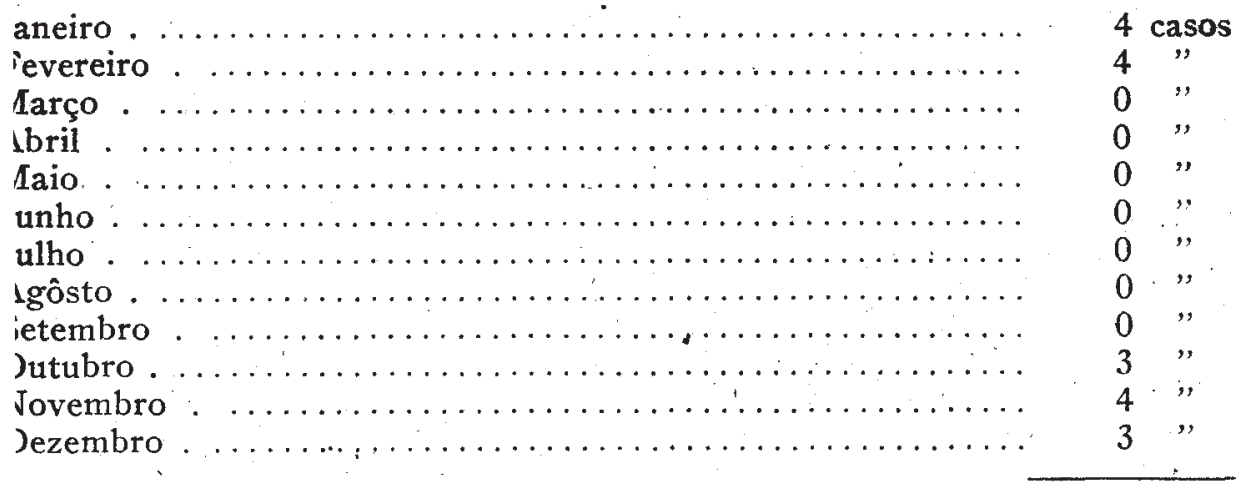

Total

18 casos 
Dos 18 casos, 14 eram do sexo masculino e 4 do feminino.

Periodo de internação:

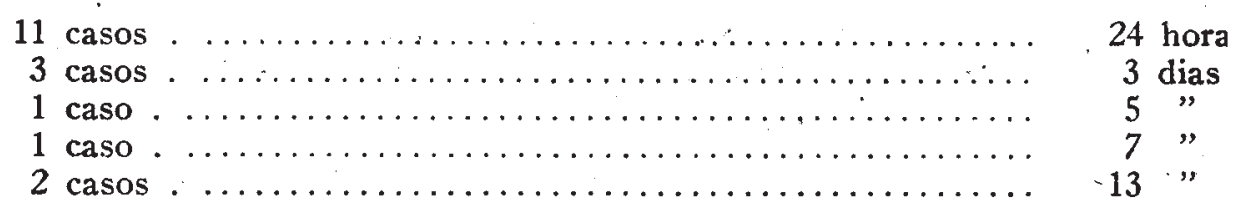

A história e o quadro clínico dêsses doentes podem ser assim sumaria dos:

A história era de adoecimento súbito. Tratava-se quase sempre de um criança que estava passando bem, brincando fora de casa, e que sùbitamenı adoecia. O que os pais notavam, de início, era vermelhidão do rosto e olh: vago. Em seguida, a criança entrava em delírio. Nesta fase os doentinhe falam coisas desconexas, não reconhecem os pais, estão agitados, executa movimentos com as mãos, como se procurassem apanhar objetos no espaç. Outros se encontram tão agitados que querem subir pelas grades das cam: ou pelas paredes. A agitação é continua.

O tratamento por nós feito consistiu na administração de luminal sód co, líquidos em abundância e purgativos salinos em alguns casos. Não fizı mos lavagem de estômago porque os doentes chegavam às nossas mãos vi rias horas após a ingestão do tóxico. Não empregamos pilocarpina.

A pesar de muitos doentes apresentarem sinais acentuados de intoxic ção, todos fơram curados.

\section{R E S U M O}

Os autores apresentam 18 casos de intoxicação pelo vegetal conhecic vulgarmente por "saia branca". Trata-se de um vegetal do grupo da belad na. Todos os casos estudados foram curados.

\section{S U M M A Y}

The Authors report 18 cases of poisoning by vegetables of the Bellad na group (Datura arborea and D. suaveolens). All the 18 patients recovere

\section{AGRADECIMENTO}

Agradecemos ao Prof. F. C. Hoehne a gentileza com que se prestoat identificar os vegetais acima referidos.

\section{BIBLIOGRAFIA}

1) Hoehne, F. C. - Plantas e Substâncias tóxicas e medicinais

2) Sportman, L. M. - Stramonium poisoning: A diagnostic problem with psychiat implication. Journal of Pedriatrics, Sept., 1946.

3) Jennings, Robert E. - Stramonium poisoning A review of Literature and Rep of two cases, Journal of Pediatrics, Vol. 6, 1935.

4) Goodman and Gilman - The Pharmacological Basis of Therapeutics. 


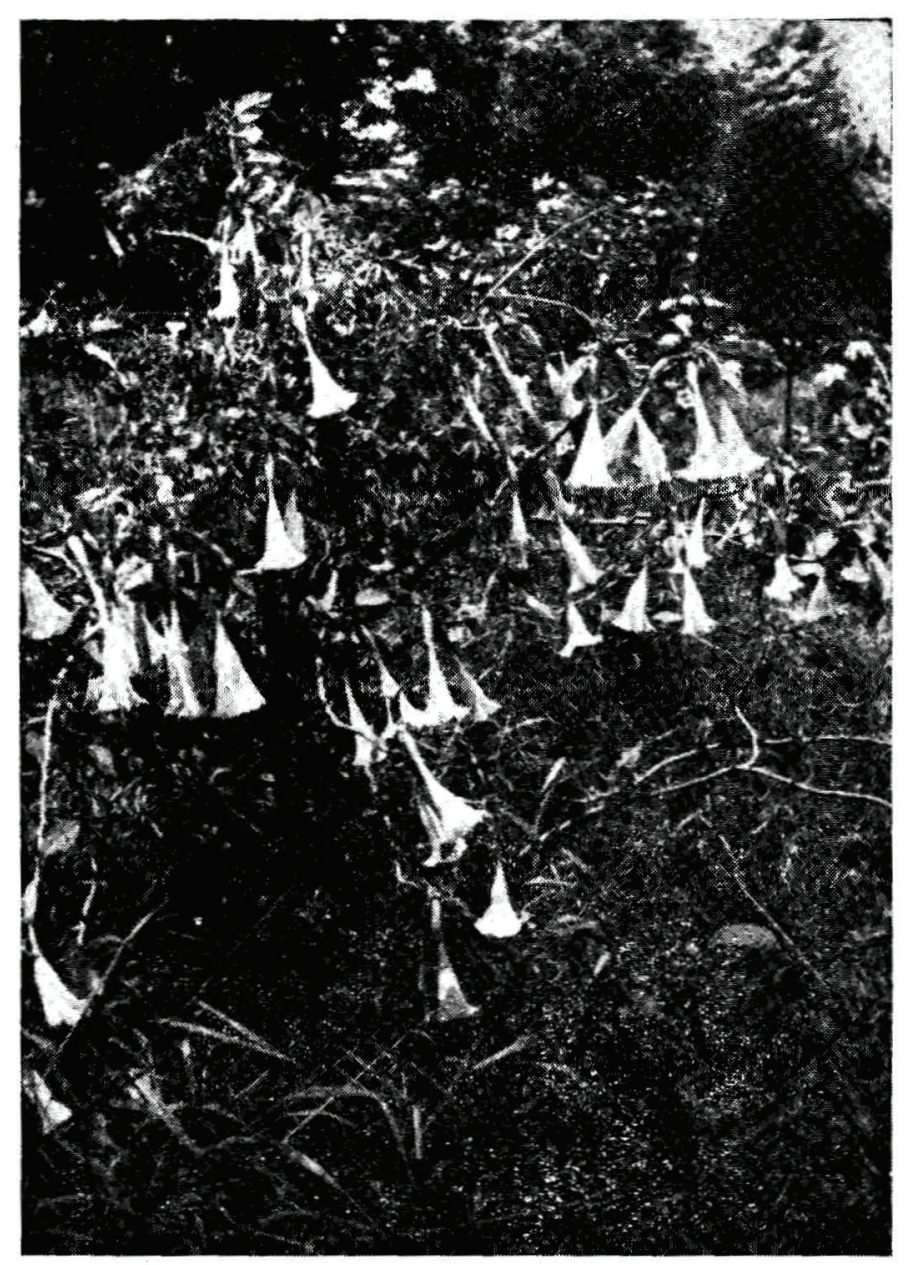

Fotografia 1 


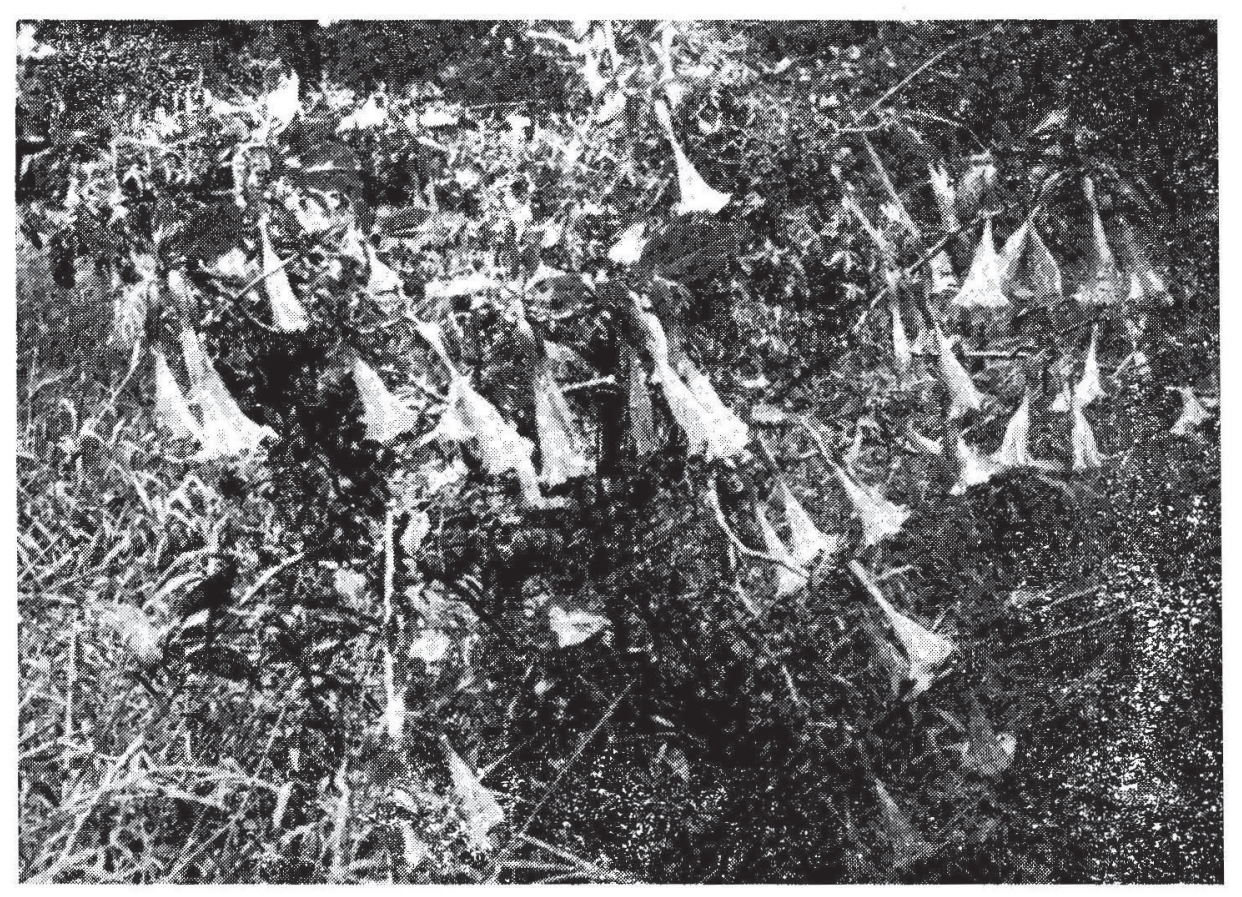

Fotografia 2 


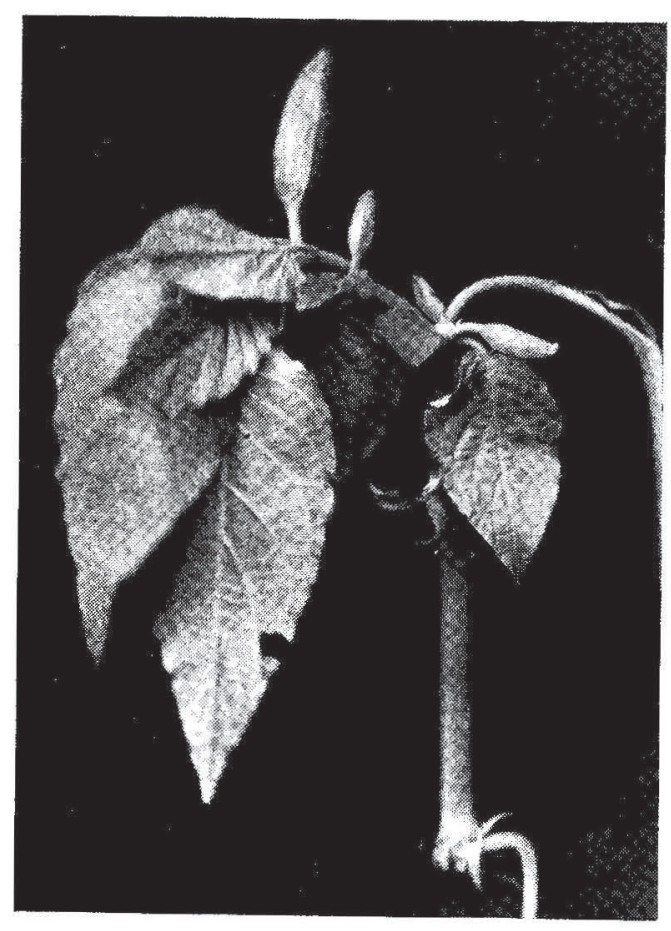

Fotografia 3

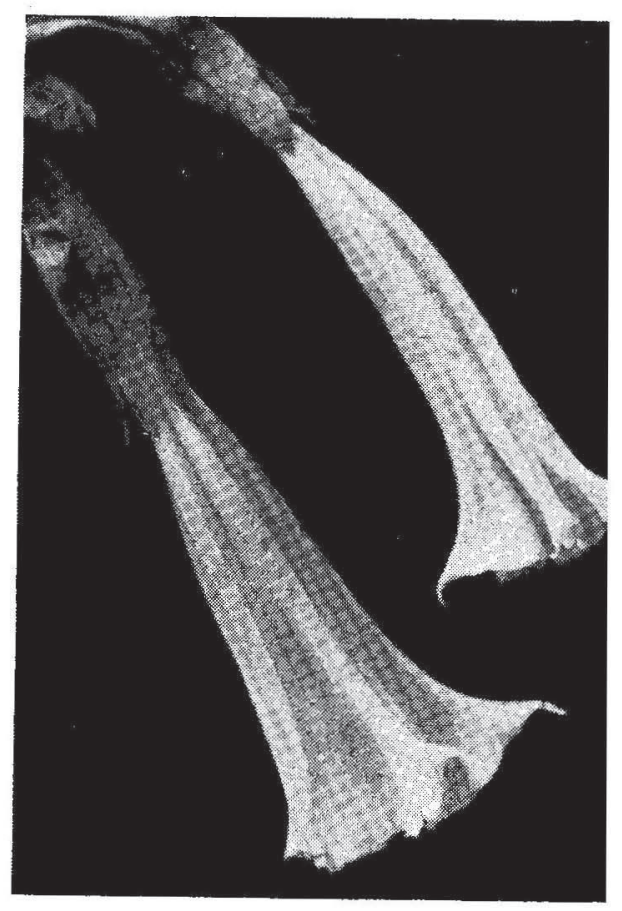

Fotografia 4

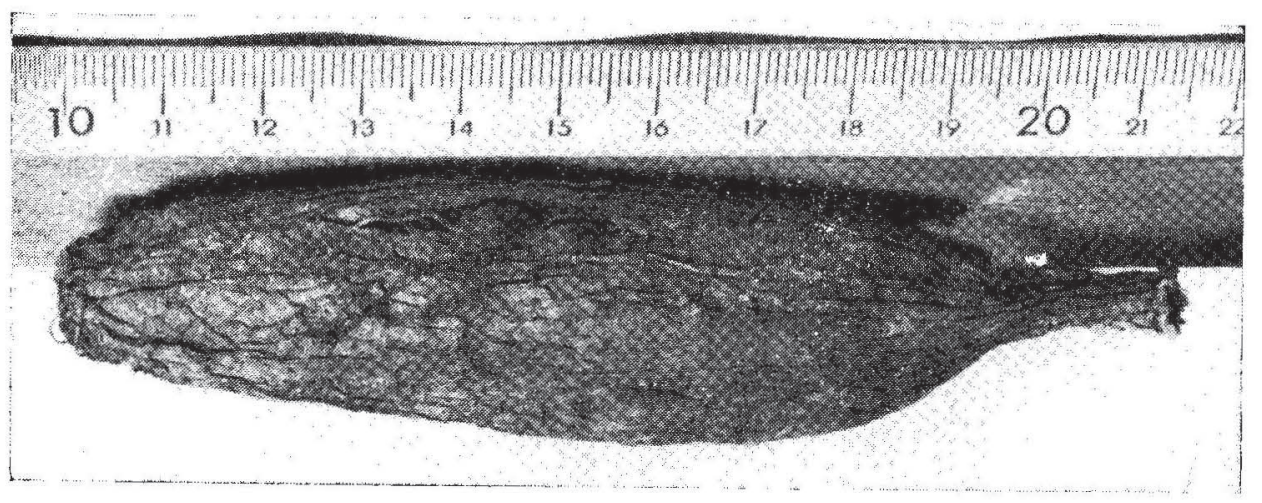

Fotografia 5 


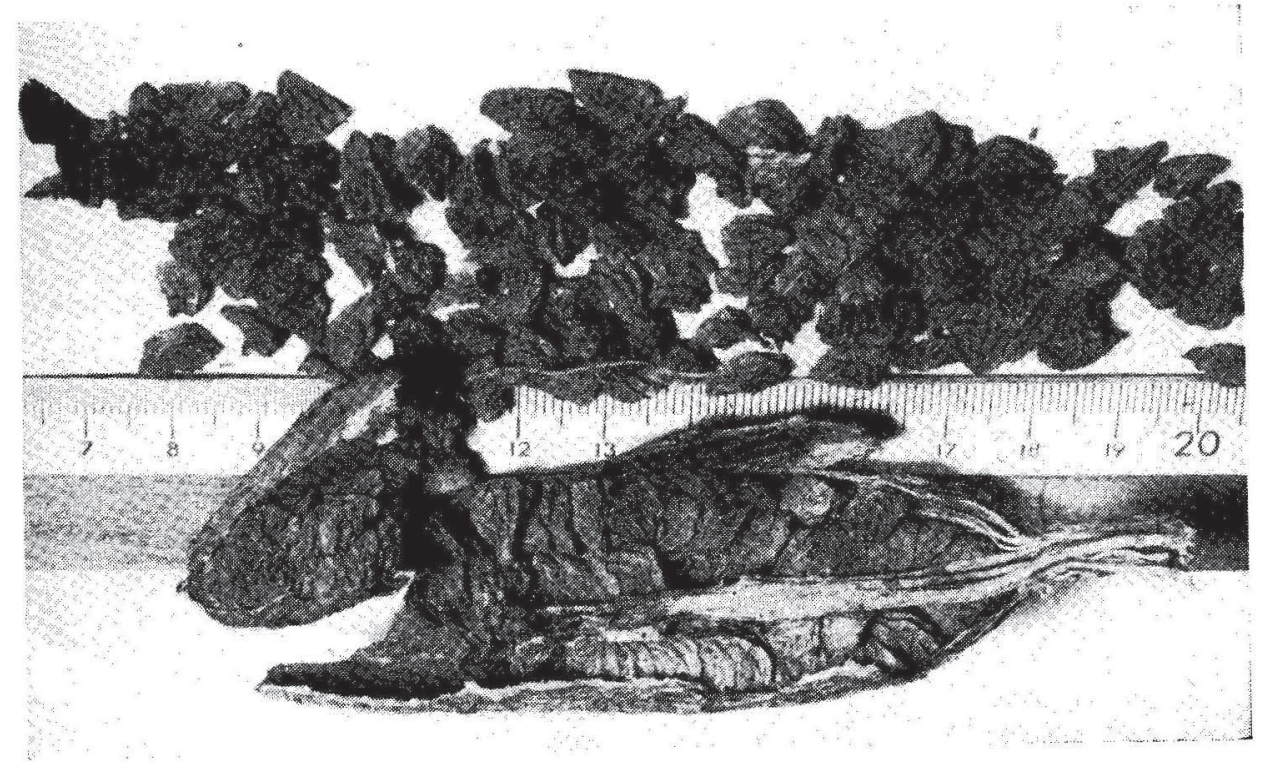

Fotografia 6 
INDICE DO VOLUME I - $1947^{\circ}$

Acido áscơrbico do mamão (Carica papaya L. 1753). Determinação do teor de $\ldots \ldots \ldots \ldots \ldots \ldots \ldots \ldots \ldots \ldots \ldots \ldots \ldots \ldots \ldots \ldots \ldots \ldots$ 171-192

Anopheles pseudotibiamaculatus Galvão e Barretto, 1941, (Diptera, Ne-

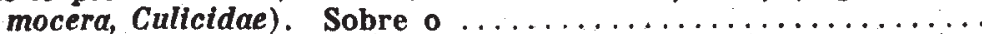

Anticorpos neutralizantes para o virus da gripe epidêmica humana tipo B (Lee), em pessôas normais, na cidade de São Paulo. Pes-

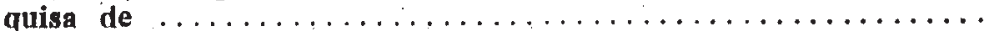

Assumpção, Lucas de - Pesquisa de anticorpos neutralizantes para 0 vírus da gripe epidêmica humana tipo B (Lee), em pessóas normais, ma cidade de São Paulo

Azevedo Netto, José Martiniano dé - A necessidade do tratamento dos

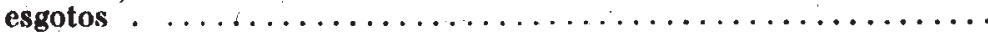

Cardoso, Francisco A. ver Ribeiro, Dorival da Fonseca

Ceratopogonideos do Brasil (Diptera, Ceratopogonidae (Heleidae), Novos

Christovão. Dacio de Almeida - - O problema sanitário dos copos, louças e talheres dos restaurantes, bares e cafés do centro da cidgde de São Paulo, revelado por inquérito bacteriológico. Causas determinantes e sugestões para a sua solução ..............

Cloridrato de Tiamina (hidrossoluvel) e iodo bismutato de tiamina (insoluvel em água). Estudos comparativos preliminares sôbre

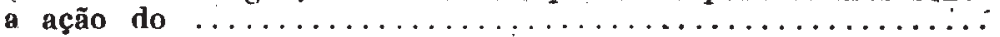

Culicoides. A' biologia e taxonomia de algumas espécies de Forcipo-

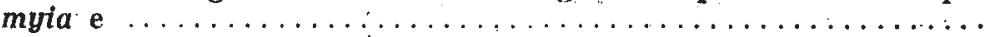
$159-170$

Doença de Manson - Pirajá da Silva ................ 5-146

Esgotos. A necessidade do tratamento dos $\ldots \ldots \ldots \ldots \ldots \ldots \ldots \ldots$ 271-280

Esquistosomiase mansoni. Subsidio ao estudo de sua distribuição

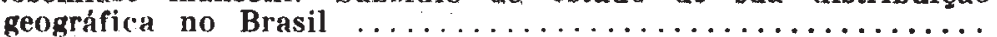

Esquistosomose mansoni. Lista bibliográfica (brasileira) sôbre a ..

Forcipomyia e Culicoides. A biologia e taxonomia de algumas espé-

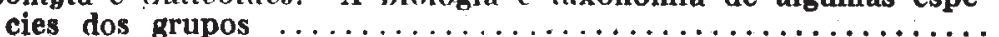

Prança, Paulo de Barros vêr 'Toledo, Luis. Aqgusto de et al. . . . . . . 287-293

Gaeta, C. J. A. vêr Lane, J. et al. . . . . . . . . . . . . . $\ldots \ldots \ldots+270$ 
Gandra, Yaro Ribeiro - Estudos comparativos preliminares sôbre a ação do cloridrato de tiamina (hidrossoluvel) e do iodo bismutado de tiamina (insoluvel em água) $\ldots \ldots \ldots \ldots \ldots \ldots \ldots \ldots$

Gripe epidêmica humana tipo $B$ (Lee). Pesquisa de anticorpos nelltralizantes para o virus da $\ldots \ldots \ldots \ldots \ldots \ldots \ldots \ldots \ldots \ldots$.

Gusmão, Hermelino Herbster - Resultados gerais do recenseamento tuberculino torácico da Universidade de São Paulo no período

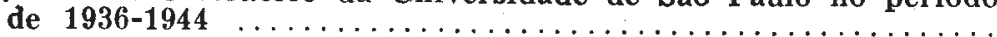

Gusmão, Hermelino Herbster vêr Paula Souza, Raphael de - 155-1.58 e 199-208

Gusmãn, Hermelino Herbster e Yassuda, Casuhe - Condições econômico-sociais e epidemiológicas de um grupo de 201 famílias de

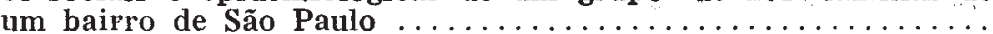

Inquérito bacteriológico. O problema sanitário dos copos, louças e lalheres dos restaurantes do centro da cidade de São Paulo

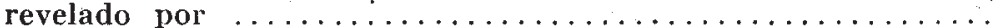

Intoxicação pela ingestão de "saia branca"

Iodo bismutato de tiamina (insoluvel em água). Estudos comparativos preliminares sôbre a ação do cloridrato de tiamina (hidros-

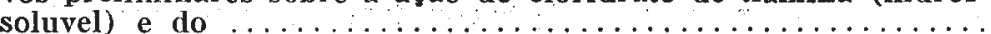

Lane, J. - A biologia e taxonomia de algumas espécies dos grupos For-

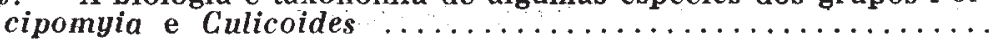

Lane, J. - Novos Ceratopogonideos do Brasil (Diptera, Ceratopogonidae

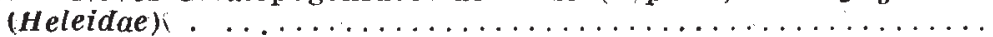

Lane, J., Rabello, E.X. e Gaeta, C.H.A. Sôbre o Anopheles pseudotibiamaculatus Galvão e Barreto, 1941 (Diptera, Nemocera, Culi-

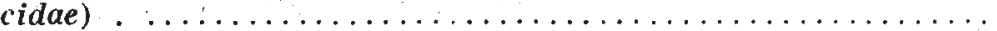

Mamão (Carica papaya L. 1753). Determinação do teor de ácido

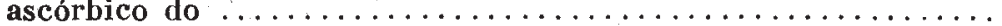

Meira, João Alves - Esquistosomiase mansoni. Subsidio ao estudo de sua incidência e distribuição geográfica no Brasil - Lista bibliográfica sôbre a esquistosomose mansoni (Doença de Manson-

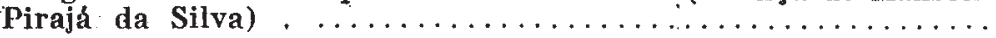

Paula Souza, Raphael de e Gusmão, Hermelino Herbster - Estudo epidemiológico e econômico-social conıparativo de famílias de côr

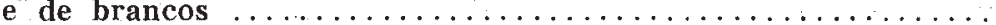

Paula Souza, Raphael de e Gúsmão, Hermelino Herbster - Estudo de 76 casos radiològicamente suspeitos encontrados no recenseamento torácico de 4.519 alunos da Universidade de S. Paulo ........

Rabello, E.X. vêr Lane, J. et al.

Recenseamento torácico de 4519 alunos da Universidade de São Paulo. Estudo de 76 casos radiologicamente suspeitos encontrados no

Recenseamento tuberculino-torácico da Universidade de São Paulo no período de 1936-1944. Resultados do ......... 
Restaurantes, bares e cafès to centro da cidade de São Paulo. 0 problema sanitário dos copos, louças e talheres dos .............

Ribeiro, Dorival da Fonseca e Cardoso, Francisco A. - Determinação do teôr de ácido ascórbióco do mamão (Carica papaya L. 1753)

Rosenburg, Cornélio Pedroso vêr Toledo, Luiz Auguslo de et al.

Rosenburg, Cornelio Pedroso verr Toledo, Luiz Anguslo de ct' al.

"Saija branca" - Intoxicação pela ingestāo de

Tiamina, cloridrato de... (hidrossoluvel) e do iodo bismutato de tiamina (insoluvel em água). Estudos comparativos preliminares

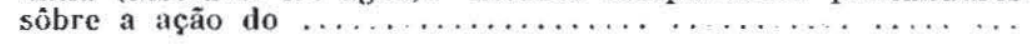

Tcledo, Luiz, Augusto de, França, Paulo de Barros e Rosenburg, CornéIio Pedroso - Intoxicação pela ingestão de "saia branca" . . . . .

Tuberculose: Resultados gerais do recenseamento tuberculino torácico da Universidade de São Paulo no periodo de $1936-1944 \ldots \ldots$.

Tuberculuse-contágio: Condições econômico-sociais a epidemiológicas de um grupo de 201 familias de $\mathrm{um}$ bairro de $\mathrm{S}$. Paulo....

Yassừ, Casuhê vêr Gusmāo, Hermelino Herbster : 